Berkala Ilmu Perpustakaan dan Informasi, Vol. 14, No. 2, Desember 2018, Hal. 177-189 DOI: 10.22146/bip.33471

ISSN 1693-7740 (Print), ISSN 2477-0361 (Online)

Tersedia online di https://jurnal.ugm.ac.id/bip

\title{
Kegiatan pendidikan dan pelatihan profesional informasi di Indonesia selama tahun 2015-2017 dalam membangun profesionalisme
}

\author{
Laksmi $^{1}$ \\ ${ }^{1}$ Departemen Ilmu Perpustakaan dan Informasi, Fakultas Ilmu Budaya, Universitas Indonesia \\ Email:laksmi@ui.ac.id
}

Naskah diterima: 25 Februari 2018, direvisi: 6 Juni 2018, disetujui: 3 Juli 2018

\begin{abstract}
ABSTRAK
Pendahuluan. Penelitian ini mengidentifikasi kegiatan diklat bagi pustakawan dan arsiparis dalam kaitannya dengan profesionalisme untuk pengembangan masyarakat pembelajar. Penelitian bertujuan untuk menggali potensi diklat tersebut di Indonesia antara 2015-2017.

Metode Penelitian. Menggunakan metode kuantitatif dengan sampel dari iklan dan laporan di media online mengenai diklat tersebut.

Data Analisis. Data yang terkumpul ditabulasikan ke dalam tabel, dihitung dengan metode tally, dan diinterpretasikan.

Hasil dan Pembahasan. Penyelenggaraan diklat mencapai 239 kali di Indonesia. Penyelenggara sebagian besar adalah lembaga pemerintah yang didominasi oleh PNRI dan ANRI. Topik diklat seimbang antara pengelolaan perpustakaan dan kearsipan, serta adanya pengembangan konsep penyelenggaraan, konten materi, dan metode pembelajaran diklat. Kredibilitas lembaga penyelenggara dan para widyaiswara yang saling mendukung menciptakan konten materi yang relevan dengan kebutuhan masyarakat.

Kesimpulan. Hal tersebut mengindikasikan bahwa pemahaman akan pentingnya bekerja secara bertanggungjawab berdasarkan ilmu, dan kesadaran untuk secara terus-menerus meningkatkan kompetensi sudah muncul pada pustakawan dan arsiparis. Namun, materi yang diberikan belum dapat menjadi bekal bagi peserta untuk mencapai kemampuan berpikir kritis. Sarannya adalah meningkatkan materi pengelolaan kearsipan, penelitian, serta soft skills.
\end{abstract}

Kata Kunci: Pendidikan dan Pelatihan; Profesional Informasi; Profesionalisme; Pustakawan; Arsiparis

\section{ABSTRACT}

Introduction. This study identifies training activities for librarians and archivists in relation to professionalism for the development of learning society. The research aims to explore the training potentials in Indonesia between 2015-2017.

Data Collection Method. The paper used quantitative method with samples of training advertisements and reports on the online media.

Analysis Data. The collected data was tabulated into the table, calculated by the tally method.Results and Discussions. The implementation of training reached 239 times in various regions in Indonesia. The organizers are dominated by PNRI and ANRI. There is a balance between library and archive management topics, as well as an improvement of the implementation, creative content, and methods of training. The organizers and the trainers support each other to create content materials to meet the society needs. Conclusions. The understanding of the importance of working in a responsible manner, based on the knowledge and awareness to continuously improve the competence of the librarian and archivist, increased. However, the material should be improved to better achieve critical thinking skills. The paper suggests improving archival, research materials, and soft skills.

Keywords: Education and Training; Information Professional; Professionalism; Librarian; Archivist 


\section{A. PENDAhUluan}

Proses pendidikan dan pelatihan (selanjutnya disingkat diklat) merupakan salah satu kunci utama dalam menciptakan sumber daya manusia (selanjutnya SDM) yang profesional. Tujuan dari program diklat ini adalah untuk meningkatkan kualitas kerja, keterampilan, produktivitas, dan pengetahuan SDM di sebuah organisasi (Stueart \& Moran, 2007).

Diklat bagi profesional informasi yang meliputi pustakawan, arsiparis, atau document controller, staf museum, pusat informasi, dan sejenisnya, berfungsi tidak hanya untuk meningkatkan keterampilan SDM dalam mengelola informasi, melainkan juga untuk membangun masyarakat pembelajar (learning society). Pada masa kini, di mana masyarakat bergantung hampir sepenuhnya pada informasi dan pengetahuan, profesional informasi bertanggungjawab untuk memotivasi masyarakat agar memiliki kemauan untuk terus mempelajari sesuatu yang baru di sepanjang usia mereka.

Dalam masyarakat yang berlimpah oleh informasi, sebagian masyarakat menjadi powerful, namun sebagian justru melemah (Desouza \& Paquette, 2011). Di satu pihak, masyarakat yang memiliki dan mampu memanfaatkan informasi dan pengetahuan, mereka menjadi lebih kritis saat menghadapi realitas. Kepemilikan pengetahuan tersebut membimbing mereka dalam menyelesaikan pekerjaan dan mengatasi permasalahan yang muncul. Atau sebaliknya, masyarakat yang memiliki informasi atau pengetahuan yang kuat, justru memanipulasi pengetahuan untuk kepentingan pribadi dan kelompok (Dahlan, 2013; Qalyubi, dkk, 2007). Di lain pihak, ketika masyarakat tidak memiliki pengetahuan, mereka menjadi lemah. Artinya, masyarakat kebingungan saat menghadapi permasalahan hidup, sebab tidak memiliki pengetahuan yang cukup dan juga kurang memahami informasi. Karena tidak faham, sebagian tertipu oleh berita hoax, beberapa tidak dapat menyusun laporan sebab tidak memahami bahasa asing, sebagian besar lainnya tidak mampu mendapatkan pekerjaan yang layak, dan lain sebagainya.
Dalam konteks masyarakat pembelajar, profesional informasi idealnya merupakan seorang pekerja yang mampu mengelola baik pengetahuan eksplisit maupun intangible (tak benda), serta memiliki kemampuan mengaplikasikan pengetahuan teoritis dan analitis untuk mengembangkan produk dan layanan yang inovatif (Raharso \& Tjahjawati, 2016; Jain, 2009).

Namun fakta di Indonesia menunjukkan sebaliknya, profesi ini dianggap hanya berperan menjaga buku dan mengelola fisik informasi (Laksmi, 2015). Mereka umumnya kurang peka terhadap substansi informasi, menganggap bahwa informasi merupakan benda mati, padahal informasi merupakan hasil konstruksi sosial; mereka juga kurang memahami teknik pemenuhan kebutuhan informasi bagi berbagai macam kelompok masyarakat.

Untuk mencegah hal tersebut, diklat untuk profesional informasi perlu diselenggarakan secara profesional. Dengan strategi diklat yang sesuai, baik dari aspek materi, tujuan, program, maupun dari aspek widyaiswara yang memiliki literasi informasi yang tinggi, diklat dapat menciptakan pustakawan dan arsiparis yang memiliki literasi informasi sampai ke tingkat mampu berpikir kritis atas informasi di dalam masyarakat dalam berbagai konteks (Shumaker, 2016).

Penelitian ini bertujuan untuk memetakan pelaksanaan diklat profesional informasi di Indonesia antara tahun 2015-2017, dan prospek pengembangannya dalam konteks profesionalisme untuk mewujudkan masyarakat pembelajar. Manfaat penelitian ini secara teoritis adalah memberikan kontribusi pada pengembangan ilmu perpustakaan dan informasi, khususnya pada topik diklat profesional informasi, sedangkan manfaatnya secara praktis adalah memberikan masukan pada lembaga informasi dalam merencanakan dan mengimplementasikan diklat kepada pegawainya maupun masyarakat luas.

Kegiatan diklat profesional informasi di Indonesia antara tahun 2015-2017 di dalam media online, baik berupa penawaran maupun berita (laporan), menunjukkan bahwa diklat di bidang perpustakaan dan kearsipan semakin 
menjamur. Dari data sementara terlihat bahwa sebagian besar lembaga penyelenggara menyajikan promosi diklat dengan topik dan tujuan yang terfokus, dan dalam waktu 3 hingga 30 hari, ditambah dengan praktik magang. Berdasarkan latar belakang tersebut, maka pertanyaan penelitian pertama adalah bagaimana pelaksanaan diklat profesional informasi di Indonesia antara tahun 2015-2017? Pertanyaan kedua adalah bagaimana kandungan profesionalisme di dalam materi yang disajikan dalam diklat?

Signifikansi penelitian ini adalah mengungkapkan tren diklat profesional informasi di Indonesia dalam kurun waktu 3 tahun. Temuan yang terungkap dapat menunjukkan tingkat profesionalisme diklat, sehingga hasil penelitian tersebut dapat digunakan sebagai umpan balik untuk perbaikan diklat yang akan dilaksanakan. Berbeda dengan penelitian-penelitian sebelumnya, kebanyakan penelitian yang sudah dilakukan hanya menekankan aspek teknis penyelenggaraan sebuah diklat. Originalitas penelitian ini bukan hanya terletak pada tujuan penelitian yang mengidentifikasi tren diklat, tetapi juga cakupannya yang bersifat nasional.

\section{B. TINJAUAN PUSTAKA \\ 1. Konsep diklat}

Diklat terdiri atas dua kata, yaitu pendidikan dan pelatihan. Pendidikan didefinisikan sebagai kegiatan membina kemampuan atau mengembangkan kemampuan berfikir individu, dan meningkatkan kemampuan untuk mengekspresikan gagasan, sedangkan pelatihan diartikan sebagai kegiatan mengembangkan keterampilan teknis.

Hal tersebut berarti bahwa diklat merupakan proses pembelajaran untuk menguasai berbagai pengetahuan dan keterampilan, sikap, nilai, serta meningkatkan rasa percaya diri agar terampil dalam melaksanakan tugas secara profesional. Pada dasarnya, diklat adalah suatu cara dan pola tindakan, yang dilakukan dalam rangka meningkatkan kemampuan, produktivitas, kualitas, moral semangat kerja, kesejahteraan dan keamanan kerja (Stueart \& Moran, 2007).
Metode pelatihan dapat dilakukan dalam situasi kerja (on the job training) dan di luar situasi kerja (off the job training). Metode pertama dilakukan melalui demo, praktik langsung, dan magang, sedangkan diklat yang dilakukan di luar situasi kerja normal, dilakukan dengan menghadiri seminar, kuliah, bermain peran, diskusi, dan metode simulasi (Qalyubi, dkk, 2007).

Kedua jenis metode pelatihan ini dapat menggunakan alat bantu berupa film, video, LCD, papan tulis, poster, dan lainnya, untuk memudahkan dalam menyimak dan mengingat. Materi perlu disusun secara sistematis dan bertahap, disesuaikan dengan tujuan yang hendak dicapai, dan berdasarkan kemampuan setiap individu. Widyaiswara juga harus mampu memotivasi dan membangun respon peserta terhadap materi. Respon tersebut diperkuat dengan konsep pembentukan perilaku.

Pada prinsipnya, materi diklat harus dapat memberikan pengaruh pada profesional informasi, untuk dapat membangun organisasi pembelajar di bidang perpustakaan dan informasi, yang berimplikasi juga membangun masyarakat pembelajar.

Proses diklat harus melalui tahapan yang berkesinambungan. Terdapat enam tahap yang diawali dengan tahap perencanaan, yaitu mengidentifikasi kebutuhan untuk mengadakan pelatihan. Tahap kedua adalah menetapkan tujuan dan sasaran pelatihan, tahap ketiga adalah menetapkan kriteria keberhasilan dengan alat ukurnya, dan tahap keempat menentukan metode pelatihan yang akan dijalankan. Tahap kelima adalah mengimplementasikan perencanaan tersebut, dan tahap terakhir mengadakan evaluasi, untuk mengidentifikasi kekuatan dan kelemahan individu (Stueart \& Moran, 2007).

\section{Profesional informasidan profesionalisme}

Profesional informasi di lembaga informasi merupakan orang-orang yang dituntut untuk lebih peka terhadap informasi, baik informasi tangible yang berupa benda maupun informasi intangible yang bukan benda dan bersifat abstrak. Secara umum, profesionalisme 
menuntut individu untuk bekerja berdasarkan ilmu, memiliki kemampuan intrapersonal (bertanggungjawab, mengenali perasaan dan emosi pribadi, percaya diri, dan introspeksi diri), serta kemampuan interpersonal (membangun hubungan baik dengan orang lain) (Litwin, 2010; Anggorowati \& Widayati, 2017).

Profesional informasi dalam konteks profesionalisme tidak terlepas dari konteks masyarakat pembelajar atau masyarakat berbasis pengetahuan (knowledge-based society). Masyarakat tersebut merupakan masyarakat yang memiliki kesadaran dan kebiasaan untuk terus menemukan dan menciptakan pengetahuan, yang mengalami perubahan sosial dan pembangunan ekonomi yang bergantung pada pemanfaatan dan informasi atau pengetahuan (Desouza \& Paquette, 2011). Mesin pengelola pengetahuan adalah kelompok intelektual atau cendekiawan dan profesional informasi.

Oleh karena itu, profesionalisme untuk pustakawan dan arsiparis menuntut mereka untuk memiliki kemampuan kebahasaan, keilmuan, teknologi informasi, serta sikap keingintahuan yang tinggi (Sulistyo-Basuki, 2013; Litwin, 2010; Jain, 2009). Seluruh kemampuan tersebut melekat dalam setiap pekerjaan profesional informasi, baik pada tataran pekerjaan fisik, maupun pada tataran kognitif, seperti mengonsep, menyusun perencanaan program kegiatan, mengevaluasi, dan memahami konten informasi (Jain, 2009).

Dalam SKKNI (Standar Kompetensi Kerja Nasional Indonesia), bahwa profesional informasi harus memiliki kemampuan soft skills, seperti berkomunikasi dan memahami karakteristik pemustaka (Anggorowati \& Widayati, 2017; Yunita, 2016). Keterampilan berkomunikasi mencakup keterampilan berbagi pengetahuan melalui tulisan. Kemampuan keilmuan mencakup kemampuan melihat fenomena berdasarkan konsep dan teori dalam konteks interdisipliner, serta kemampuan meneliti dan meningkatkan keingintahuan atas fenomena, mampu menerima pengetahuan baru, jujur, dan menghargai keterbukaan.

Kemampuan soft skills lainnya adalah kemampuan dalam bidang pemasaran.
Lembaga informasi, terutama perpustakaan, pusat informasi, arsip, dan museum, dikenal sebagai lembaga yang kurang mendapatkan apresiasi masyarakat (Rubin, 2016). Tugas profesional informasi adalah mengubah imaji masyarakat bahwa lembaga informasi yang dianggap sebagai 'gudang' menjadi imaji sebagai pusat pembelajaran seumur hidup dan pelestari budaya bangsa.

Tugas yang paling berat adalah menjadikan masyarakat sebagai masyarakat pembelajar. Tugas tersebut menuntut profesional informasi untuk menjadikan diri sendiri terlebih dahulu sebagai individu pembelajar, sehingga dapat menularkannya kepada masyarakat (Jain, 2009; Laksmi \& Wijayanti, 2016).

\section{METODE PENELITIAN}

Penelitian ini menggunakan pendekatan kuantitatif, dengan melihat generalisasi profesionalisme pada diklat di bidang perpustakaan dan kearsipan. Sampel mencakup teks iklan atau berita di media online antara tahun 2015 hingga 2017, berdasarkan karakteristik yang sudah ditentukan (purposive sampling). Karakteristik tersebut yakni data yang memiliki informasi lengkap, yaitu nama dan tujuan diklat, penyelenggara, waktu dan tempat, sasaran peserta, serta materi diklat (Pickard, 2007). Data yang terkumpul dianalisis dengan metode tally, yaitu menghitung jumlah/frekuensi. Rumusnya adalah sebagai berikut:

$$
P=f / N \times 100 \%
$$

$\mathrm{P}$ adalah persentase, $\mathrm{f}$ adalah frekuensi jawaban pada setiap jawaban, dan $\mathrm{N}$ merupakan jumlah frekuensi total/sampel yang diolah. Persentase yang diperoleh ditafsirkan dengan menggunakan parameter berikut:

$0 \% \quad=$ tidak satu pun

$1 \%-25 \%=$ sebagian kecil

$26 \%-49 \%=$ hampir setengahnya

$50 \% \quad=$ setengahnya

$51 \%-75 \%=$ sebagian besar

$76 \%-99 \%=$ hampir seluruhnya

$100 \%=$ seluruhnya 
Analisis dilanjutkan dengan mengelompokkan dan mengkaitkan hasil temuan, untuk menjelaskan fenomena diklat di bidang perpustakaan dan kearsipan di Indonesia.

\section{HASIL DAN PEMBAHASAN \\ 1. Hasil penelitian \\ a. Frekuensi diklat}

Total sampel diklat di bidang perpustakaan dan kearsipan antara tahun 2015-2017 berjumlah 239 diklat. Jumlah tersebut merupakan hasil penelusuran dari media online, tidak termasuk diklat yang diumumkan di media cetak. Dari jumlah total 239, distribusi frekuensi pelaksanaan diklat dalam kurun waktu 3 tahun terlihat meningkat secara bertahap. Pada tahun 2015 terdapat 58 diklat, kemudian tahun 2016 menjadi 89, dan tahun 2017 meningkat ke 91. Hal tersebut menunjukkan adanya peningkatan kesadaran pada pustakawan dan arsiparis akan kebutuhan untuk bekerja secara profesional. Hal tersebut menunjukkan bahwa profesi di bidang ini sedang dibutuhkan oleh masyarakat, mengingat saat ini masyarakat sedang giat membangun masyarakat pembelajar.

\section{b. Tujuan diklat}

Dilihat dari konteks profesionalisme, 239 diklat yang teridentifikasi dalam penelitian ini $(100 \%)$ memiliki tujuan yang sama, yaitu untuk mengembangkan pengetahuan, keterampilan teknis, pengembangan layanan di bidang perpustakaan dan kearsipan, serta kepribadian. Tujuan dibedakan ke dalam 3 bagian, yaitu:

1) Bagi pengelola, diklat bertujuan untuk memberikan keterampilan teknis dan konseptual tentang manajemen, otomasi, serta sertifikasi kompetensi bagi guru dan kepala perpustakaan sekolah/madrasah.

2) Bagi masyarakat, diklat bertujuan untuk menjadikan perpustakaan sebagai tempat untuk belajar dan rekreasi, meningkatkan peran aktif masyarakat dan budaya baca.

3) Diklat bertujuan agar widyaiswara mampu menguasai teknik mengajar untuk mentransfer ilmu dengan baik.

Dari ketiga bagian tersebut, profesionalisme terlihat dalam tujuan diklat yang sebagian besar
(80\%) ditujukan untuk pengembangan dan peningkatan pengetahuan dan keterampilan pengelola perpustakaan dan arsip, namun hanya sebagian kecil diklat $(20 \%)$ bertujuan membangun masyarakat pembelajar.

\section{c. Sasaran diklat}

Selain frekuensi dan tujuan, profesionalisme diekspresikan pada pengaturan sasaran diklat. Pengaturan tersebut terlihat pada kesesuaian tujuan dengan sasaran, termasuk persyaratan tertentu bagi peserta. Data menunjukkan bahwa sebagian besar sasaran adalah guru dan kepala sekolah/madrasah yang ditempatkan atau sudah bekerja di perpustakaan. Saat ini, perpustakaan sekolah/madrasah di Indonesia masih belum memadai, baik dari segi jumlah maupun kualitasnya, dan menempati urutan terendah di seluruh ASEAN (Eppang, 2016). Sasaran diklat lainnya adalah seluruh profesi, mulai dari pengajar, dosen, tenaga perpustakaan sekolah, pengelola TBM, staf di pemerintah dan swasta, tenaga perpustakaan di kecamatan dan desa, Kepala Desa, Perangkat Desa, LKMD, Kader PKK, Karangtaruna, Pengelola Perpustakaan Desa (Perpusdes), dan lain sebagainya.

Sasaran diklat yang ditujukan untuk pegawai pemerintah adalah mereka yang memiliki jabatan fungsional, dengan prasyarat yang lebih berat, seperti misalnya sudah bekerja minimal 5 tahun, memiliki pendidikan akhir DIII atau S1, dan syarat lainnya. Sasaran diklat TOT dituntut memiliki pendidikan minimal Sarjana Ilmu Perpustakaan/sudah menjadi pustakawan, dan Sarjana Non Perpustakaan tetapi sudah mengikuti Diklat CPTA (calon pegawai tingkat ahli). Umumnya program ini ditujukan untuk pegawai PNRI, ANRI, dan pegawai Pemerintah Daerah (Pemda).

Pada umumnya, jumlah peserta dalam satu angkatan rata-rata 20-30 orang, tetapi ada juga diklat dengan peserta sebanyak 70-100 orang. Jumlah peserta yang terlalu banyak akan menyulitkan proses pembelajaran, sehingga output tidak maksimal. Diklat perpustakaan dan kearsipan membutuhkan praktik dengan peralatan yang sesungguhnya, dan pengawasan serta bimbingan personal dari widyaiswara. 


\section{d. Penyelenggara diklat}

Kualitas konten materi dalam diklat, sebagai salah satu unsur yang membangun profesionalisme, tergantung pada kredibilitas dan integritas penyelenggaranya, sehingga dapat menjamin kualitas materi diklat (Qalyubi, dkk, 2007). Penyelenggara dibedakan ke dalam 4 kelompok, yaitu lembaga pemerintah, perguruan tinggi, asosiasi, dan yayasan. Grafik 1. menunjukkan bahwa penyelenggara yang paling banyak menawarkan diklat adalah PNRI, ANRI, dan Pemda. Berdasarkan Undangundang, ketiganya merupakan lembaga pembina.

Pada Gambar 1, terlihat bahwa lembaga pemerintah seperti PNRI dan ANRI menyusun kegiatan diklat yang terstruktur dan terencana dalam 1 tahun untuk topik dan target sasaran yang berbeda-beda. Peserta bisa memilih waktu sesuai kebutuhan dan ketersediaan waktu masing-masing. Penjadwalan tersebut dilakukan oleh lembaga penyelenggara diklat agar peserta dapat menyesuai-kan jadwal masing-masing (Anggorowati \& Widayati, 2017).

Penyelenggara lainnya adalah Dinas Pendidikan atau Dinas Perpustakaan dan Kearsipan dari Pemda, yang disebut BPAD, KPAD, atau Bapusipda; disusul oleh asosiasi perpustakaan, lembaga swasta, dan komunitas; perguruan tinggi; dan terakhir oleh yayasan. Sebagian besar lembaga lainnya juga menawarkan diklat serupa yang terstruktur dan terencana dalam 1 tahun.

Selain PNRI dan ANRI yang berwenang menjadikan peserta sebagai profesional, perguruan tinggi UIN Sunan Kalijaga memiliki izin sebagai penyelenggara diklat yang memberikan sertifikasi kepada Kepala Perpustakaan Sekolah/Madrasah. Izin tersebut berdasarkan Keputusan Direktur Jenderal Pendidikan Islam Kementerian Agama Nomor 1081 Tahun 2015 Tanggal 23 Februari 2015.

Beberapa lembaga melakukan kerjasama untuk menyelenggarakan diklat, misalnya Universitas Negeri Malang bekerjasama dengan Majelis Pendidikan Katolik (tahun 2016) dalam diklat perpustakaan; atau ATPUSI Lampung dengan Komunitas SLiMS Lampung dalam diklat otomasi perpustakaan berbasis SLiMS (tahun 2017), dan masih banyak lagi. Tabel 1. menunjukkan daftar rincian empat kategori penyelenggara diklat.

Profesionalisme dalam pelaksanaan diklat juga terlihat pada penyediaan widyaiswara atau pelatih yang juga dituntut untuk kredibel. Widyaiswara rata-rata berasal dari lembaga yang bergerak di bidang perpustakaan dan kearsipan, seperti PNRI, ANRI, BPAD/KPAD, pengajar dari perguruan tinggi, dan asosiasi. Pengumuman diklat di media online menyatakan bahwa widyaiswara adalah orang yang benar-benar kompeten di bidang perpustakaan dan kearsipan, telah bekerja selama puluhan tahun di bidang terkait, menjabat sebagai pejabat fungsional Arsiparis tingkat Ahli, pernah menduduki posisi Pustakawan atau Arsiparis Utama, atau Kepala Dinas Perpustakaan dan Kearsipan Daerah, sebagai pengajar bidang perpustakaan di perguruan tinggi, dan seterusnya. Berikut ini contoh sebuah pengumuman Pelatihan Perpustakaan Sekolah Muhammadiyah di media online (tahun 2017):

"Pembicara senior, Bp. Drs. Romodon, M.Si (Pustakawan Utama, Kepala Perpustakaan Univ. Nusantara, Pembina FPPT Nusantara)."

Penyelenggara juga menyusun diklatnya dalam kurun waktu yang agak panjang. Waktu penyelenggaraan dirancang dalam waktu sekitar 3 hari, 40 jam, hingga 1 bulan. Hanya sebagian kecil diklat (5\%) yang dilakukan dalam waktu 1 hari. Sebagian besar pengumuman diklat menyebutkan tambahan waktu sekitar 7 hari hingga 3 minggu untuk tugas mandiri dalam bentuk praktik magang. Contoh diklat dari ANRI (tahun 2017):

"Diklat dilaksanakan secara klasikal selama 10 hari termasuk check in dan check out, serta magang/kerja mandiri di masingmasing instansi peserta diklat selama 10 hari kerja. Pada sesi akhir diklat ini peserta diwajibkan membuat laporan hasil praktik kerja dan dikirimkan paling lambat 7 hari kelender."

Selain itu, iklan diklat ada yang mengharuskan peserta untuk melakukan kunjungan ke tempat 
yang sudah ditentukan, untuk mengamati lembaga yang sudah mapan dan pembelajaran langsung dari staf di lapangan.

Sistematika pembelajaran tersebut menunjukkan profesionalisme. Proses pembelajaran yang baik dimulai dari tahap yang paling mudah ke tahap yang paling kompleks, dan dilakukan dengan diskusi dan magang atau belajar dalam situasi kerja (on the job training) (Qalyubi, dkk, 2007). Hampir seluruh diklat (95\%) menyusun tahapan pembelajaran secara sistematis. Misalnya, pelatihan otomasi dimulai dari pengenalan sistem informasi, dilanjutkan dengan konsep tentang perangkat lunak (SLiMS, e-arsip, dsb), kemudian penjelasan tentang cara mengunduh, menginstal, dan memanfaatkannya, tahun 2015, 2016, 2017.

Sebaran penyelenggaraan diklat juga terlihat hampir merata di seluruh wilayah Indonesia, seperti kota-kota di pulau Jawa (Jakarta, Depok, Bandung, Yogyakarta, Malang, Sidoarjo, dan sebagainya), Bali, Nusa Tenggara Barat, Sumatera, Sulawesi, Kalimantan. Tidak menutup kemungkinan, pengumuman diklat di luar media online akan lebih banyak dan cakupannya lebih luas.

\section{e. Topik dan materi diklat}

Dari jumlah total tersebut, topik diklat yang serupa akan digabung menjadi satu, dan topik yang berbeda akan didata ke dalam kolom yang berbeda. Topik dan materi diklat dibedakan ke dalam 4 kategori, yaitu diklat pengelolaan perpustakaan, diklat untuk kepala dan pengelola perpustakaan sekolah/madrasah, diklat pengelolaan arsip, dan diklat gabungan pengelolaan arsip dan perpustakaan. Sebagian kecil diklat (20\%) menggabungkan topik pengelolaan perpustakaan dengan laboran.

Pada Gambar 2, data menunjukkan bahwa hampir seluruhnya $(90 \%)$ topik dan materi diklat difokuskan pada topik pengelolaan perpustakaan dan kearsipan.

Gambar 2 menunjukkan bahwa kategori pertama, yaitu topik pengelolaan perpustakaan adalah topik yang paling banyak ditawarkan dalam kurun waktu 3 tahun, yaitu sebanyak 87 diklat. Topik tersebut lebih banyak difokuskan pada pengelolaan teknis perpustakaan, seperti manajemen perpustakaan yang mencakup fungsi manajemen, visi dan misi, analisis SWOT, pengembangan prosedur kerja, pengembangan koleksi, analisis subjek, tata letak serta display perpustakaan, sistem manajemen mutu kebutuhan ruang perpustakaan menurut SNP untuk SD, SMP, SMA. Dalam kategori tersebut, topik dengan materi yang juga banyak dilakukan adalah otomasi perpustakaan. Teknologi informasi memudahkan akses dan pengelolaan perpustakaan melalui perangkat lunak. Biasanya materi ini mencakup penggunaan perangkat lunak SLiMS dan NLISLite, atau My Hand dan e-arsip. Praktik mencakup cara mengunduh, menginstal, dan menggunakan program tersebut.

Kategori kedua merupakan topik pengelolaan perpustakaan, khusus untuk kepala perpustakaan dan pengelola perpustakaan sekolah/madrasah, yaitu sebanyak 11 diklat. Materi untuk kepala perpustakaan diisi dengan kepemimpinan dan kepustakawanan, sedangkan untuk pengelola hanya diberikan pengetahuan perpustakaan. Kategori diklat pengelolaan perpustakaan untuk sekolah/madrasah ini cukup signifikan dilakukan di masyarakat Indonesia, karena perpustakaan sekolah merupakan perpustakaan yang paling memprihatinkan dibanding perpustakaan jenis lainnya (Eppang, 2016).

Gambar 2 juga menunjukkan bahwa diklat kearsipan sebanyak 82 diklat memberikan materi pengelolaan kearsipan, mulai dari manajemen arsip dinamis, tata persuratan (pengelolaan surat masuk dan keluar, penomoran, distribusi, dan penyimpanan), penyimpanan dan pemusnahan arsip, dan materi mengenai pengelolaan operasional sehari-hari arsip lembaga. Beberapa diklat memberikan materi pengenalan dasar, yang bertujuan untuk memberi kesadaran bagi masyarakat akan pentingnya mengelola arsip. Fakta tersebut dapat dimaknai bahwa sebagian besar masyarakat masih belum menyadari hal tersebut proporsional. Kategori diklat gabungan perpustakaan dan kearsipan terdapat 27 diklat. 
Keterangan di dalam media online menjelaskan bahwa materi yang diberikan adalah mengenai pekerjaan teknis perpustakaan dan kearsipan.

Dalam kategori ini, hanya sebagian kecil diklat yang menawarkan materi soft skills. Sebuah diklat perpustakaan sekolah menawarkan materi tentang literatur anak dan remaja dan bahasa Inggris untuk pustakawan sekolah. Sayangnya, frekuensi diklat ini hanya 2 kali dalam kurun waktu 3 tahun. Materi lainnya adalah peningkatan layanan. Kompetensi widyaiswara yang memberikan materi ini kadang-kadang disampaikan oleh widyaiswara di luar bidang ilmu terkait, seperti konsultan di bidang marketing. Dalam diklat layanan prima, materi difokuskan pada 1) membuat pelanggan merasa penting; 2) melayani dengan ramah, tepat, dan cepat; 3) meningkatkan kepuasan pelanggan.

Agar pelaksanaan diklat berjalan lancar dan mencapai tujuan, perlu dibuat diklat dengan topik dan materi yang dapat mendukung hal tersebut. Topik diklat dibedakan ke dalam 3 kelompok, yaitu diklat untuk staf lembaga pembina (PNRI, ANRI, BPAD/KPAD/ DISPUSIPDA), diklat untuk widyaiswara, serta diklat untuk memberikan keterampilan menulis dan membangun minat baca pada masyarakat.

1) Topik diklat untuk jabatan profesional pustakawan dan arsiparis untuk staf pemerintah, sebanyak 19 diklat. PNRI, ANRI, dan BPAD/KPAD/ DISPUSIPDA berupaya memperkuat jajaran mereka sebagai lembaga pembina bidang perpustakaan dan informasi. Dengan meningkatkan kompetensi staf, lembaga mereka tetap memiliki otoritas dan nama baik sebagai lembaga pembina.

2) Topik diklat yang kedua adalah TOT, sejumlah 7. Diklat TOT (training for trainer) memberikan materi untuk memperkuat widyaiswara agar dapat mentransfer pengetahuan secara optimal. Tugas mengajarkan materi perpustakaan dan kearsipan kepada masyarakat, serta meyakinkan mereka bahwa keduanya penting, bukan pekerjaan mudah (Qalyubi, dkk, 2007). Seluruh topik dan materi diklat dirancang untuk memberi pembekalan bagi para peserta untuk mencapai profesionalisme dalam mentransfer pengetahuan.

3) Topik ketiga adalah diklat menulis dan menjadi penyuluh minat baca, sebanyak 6 . Kategori ini memberikan materi yang mengajarkan kemampuan mengekspresikan gagasan dalam tulisan, mengkaji informasi, memahami hak kekayaan intelektual, serta metode menanamkan budaya baca. Dalam era digitalisasi, seorang profesional informasi perlu memiliki soft skills berbagi pengetahuan, komunikasi, serta kerjasama dalam tim (Yunita, 2016).

\section{Diskusi}

Profesionalisme dalam diklat terlihat pada implementasi diklat, khususnya pada proses penyelenggaraannya. Antara tahun 2015-2017, diklat profesional informasi di Indonesia yang muncul di media online berjumlah 239 . Frekuensi diklat meningkat secara bertahap dan tersebar di seluruh wilayah Indonesia, dan diperkuat oleh pemberian apresiasi dalam bentuk sertifikasi dan kenaikan jabatan fungsional.

Profesionalisme terlihat pada lembaga penyelenggara dengan kredibilitas tinggi yang menjadi jaminan kualitas diklat. Dominasi oleh 2 lembaga negara, yaitu PNRI dan ANRI, lembaga pemerintah non departemen (LPND) yang berfungsi sebagai pembina, rujukan, deposit, penelitian, pelestarian, dan pusat jejaring. Berdasarkan fungsi tersebut, PNRI menawarkan diklat perpustakaan untuk stafnya dan masyarakat sebanyak 15 diklat dalam setahun, sedangkan ANRI menawarkan diklat kearsipan sebanyak 28 jenis, baik untuk staf internal maupun untuk masyarakat umum.

Sementara itu, lembaga lain yang menyelenggarakan diklat adalah sejumlah asosiasi di bidang perpustakaan, komunitas, dan lembaga swasta lainnya yang bergerak di bidang yang sama maupun yang berbeda, memiliki kompetensi perpustakaan dan teknologi informasi yang memadai. Penyelenggara lain dari lembaga swasta dan konsultan, hampir semuanya memperkuat materi di bidang layanan, komunikasi, dan promosi. Perguruan 
tinggi, khususnya UPT, memiliki pengetahuan, kompetensi, dan pengalaman di dunia pendidikan, yang dimanfaatkan untuk diajarkan ke dalam diklat.

Tidak jauh berbeda dengan lembaga penyelenggara, widyaiswara diklat harus memiliki latar belakang pendidikan dan pengalaman yang sesuai (Qalyubi, dkk, 2007). Selain menjaga kualitas diklat, otoritas widyaiswara dapat digunakan sebagai sarana promosi diklat. Sebagian besar penyelenggara menyebutkan bahwa widyaiswara adalah seseorang yang sudah dikenal, lulusan di bidang terkait, dengan pengalaman kerja dan posisi jabatan yang sudah tinggi.

Kandungan profesionalisme juga terlihat pada materinya. Materi tidak hanya mencakup praktik, tetapi juga materi intelektual yang menjadikan peserta mampu memahami dan menerapkan teori, melakukan analisis dan sintesis, termasuk beretika (Anggorowati \& Widayati, 2017; Jain, 2009). Data menunjukkan bahwa hampir seluruh materi diklat (95\%) masih didominasi oleh pengetahuan tentang praktik.

Materi konseptual lainnya adalah mengenai filsafat kearsipan, metodologi penelitian, dan teknik penulisan karya ilmiah (Jain, 2009). Diklat dengan materi tersebut ditujukan bagi kelompok target yang sudah memiliki pengetahuan dan keterampilan di atas pengetahuan dasar, yaitu pustakawan dan arsiparis tingkat ahli dan juga para widyaiswara.

Materi yang bersifat konseptual juga mencakup soft skills, khususnya yang mengasah daya analisis dalam kognisi manusia melalui kompetensi menulis dan membaca (Shumaker, 2016). Materi ini seharusnya menjadi materi utama, karena dapat menciptakan SDM yang mampu berpikir kritis (Desouza \& Paquette, 2011). Sayangnya, diklat yang mengajarkan soft skills hanya 6 . Kompetensi ini mendorong peserta untuk memahami makna di balik informasi, mengidentifikasi kebenaran maupun kepentingan tertentu di balik sebuah informasi, memahami sistem sosial masyarakat, serta bersikap terbuka, jujur, dan netral terhadap pengetahuan baru(Yunita, 2016).
Profesionalisme terlihat pada metode pembelajarannya, seperti waktu yang relatif panjang, agar peserta memiliki waktu untuk proses penyerapan. Diklat di bidang ini hampir seluruhnya $(90 \%)$ melakukan diklat dalam kurun waktu yang relatif panjang, yaitu 3 hingga 30 hari atau lebih, ditambah dengan magang selama 45 hari kerja.

Apalagi dalam diklat yang bertujuan untuk memperkenalkan perpustakaan atau kearsipan, metode pembelajarannya membutuhkan waktu yang lebih panjang, sebab penjelasan untuk masyarakat yang masih awam harus diikuti oleh praktik agar mudah dipahami. Tugas mandiri dalam bentuk praktik magang atau kunjungan ke tempat yang dianggap berkinerja baik memberikan kesempatan bagi peserta agar dapat menyerap dan menerapkan ilmu dengan lebih baik.

Untuk diklat yang ditujukan kepada mereka yang sudah memiliki dasar, seperti pustakawan yang akan menjalani kenaikan jabatan, diklat memberi persyaratan lebih tinggi kepada mereka. Syaratnya meliputi latar belakang pendidikan S1, lama bekerja, jenjang kepangkatan, batas usia, dan kemampuan lainnya, serta sehat jasmani dan rohani. Di akhir diklat, peserta dievaluasi. Penerapan evaluasi paling tidak membuat peserta bersungguhsungguh untuk memahami dan menguasai materi. Tidak hanya itu, metode apresiasi dalam bentuk sertifikasi dan kenaikan pangkat juga menjadi penyemangat peserta (Stueart \& Moran, 2007).

Metode pembelajaran yang digunakan harus sesuai agar tercapai profesionalisme. Pada Diklat TOT, metode pembelajaran yang digunakan yakni ceramah/tanya jawab, praktik di kelas, studi banding dan micro teaching atau praktik mengajar. Peserta diklat TOT juga wajib studi banding ke Badan Diklat Kemendagri untuk memperoleh pengetahuan tambahan dalam teknik mengajar.

Metode pembelajarannya, penyajian materi dilakukan melalui metode ceramah, tanya jawab, praktik, magang, kunjungan, diskusi (studi kasus), dan evaluasi. Seluruh metode tersebut memberi kesempatan semua peserta 
untuk aktif dan belajar mandiri, termasuk bersikap dan berperilaku (Stueart \& Moran, 2007). Kedua aspek penilaian tersebut mencerminkan nilai kedisiplinan, kerjasama, dan prakarsa.

\section{E. KESIMPULAN}

Profesionalisme dalam diklat di Indonesia di bidang perpustakaan dan kearsipan antara tahun 2015 hingga 2017 sudah muncul, meskipun baru sebagian kecil diklat yang memberikan konten materi yang bertujuan meningkatkan kemampuan intelektual. Meskipun hampir seluruh diklat menggunakan metode cukup pembelajaran praktik magang, namun materi yang diberikan belum dapat menjadi bekal bagi peserta untuk mencapai kemampuan berpikir kritis yang dibutuhkan dalam konteks membangun masyarakat pembelajar.

Saran yang ditawarkan pada diklat di bidang perpustakaan dan informasi yaknimeningkatkan materi yang mengembangkan diklat menulis, meneliti, materi minat baca masyarakat dan materi soft skills; mengembangkan materi mengenai pengolaan kearsipan; mengembangkan materi yang mengasah intelektual, seperti menyertakan materi keilmuan, materi penelitian, dan menulis. Terakhir, penelitian ini dapat dikembangkan lebih lanjut kepada proses pembelajaran dan menganalisis proses adopsi dari para peserta.

\section{DAFTAR PUSTAKA}

Anggorowati, D.N. \& Widayati, R.W. (2017). Peran forum pustakawan dalam pengembangan profesionalisme pustakawan di lingkungan Universitas Gadjah Mada. Diakses 8 Januari 2018, dari http://jurnal.ugm.ac.id/bip. Berkala Ilmu Perpstakaan dan Informasi. 13(2), 117-130. DOI: 10.22146/bip.27499.

Desouza, K.C. \& Paquette, S. (2011). Knowledge management: An introduction. New York: Neal-Schuman Publishers.

Eppang, L. (Ed.). (2016). Perpustakaan di Indonesia urutan terendah di ASEAN. 13 Oktober 2016. Diakses 23 Februari 2018, dari http://www.netralnews.com/ news/pendidikan/read/29684/perpustakaan. di.indonesia.urutan.terendah.di.asean
Eze, J.U. (2012). Staff training programmes in Nigerian public libraries: the case of Enugu State Public Library. Library Philosophy and Practice (e-journal). Paper 775. http://digitalcommons.unl.edu/libphilprac/ 775

Jain, P. (2009). Knowledge management for $21^{\text {st }}$ century information professionals. Journal of Knowledge Management Practice, 10(2), []. Diakses 10 September 2017, dari http: www.tlainc.com/articl193.htm

Jain, P. \& Mutula, S. (2008). Libraries as learning organisations: Implications for knowledge management. Library Hi Tech News. 2( 8), $10-14$. D O I $10.1108 / 07419050810931273$.

Kostagiolas, P.A. (2012). Managing knowledge capital in public libraries for a knowledgedriven socioeconomic environment. Paper presented at World Library and Information Congress: 78th IFLA General Conference and Assembly, Helsinki. Diakses 25 Januari 2018, dari http://conference.ifla.org/ifla78.

Laksmi \& Inamullah, M.H. (2017). The implementation of learning organization in building intellectual capital in Nusantara Library. Paper presented at The Asia-Pacific Research in Social Sciences and Humanities (The 2nd Aprish), 27-29 September 2017, Hotel Margo, Depok.

Laksmi \& Wijayanti, L. (2016). Conflict of interest in Indonesia university libraries in building intelllectual capital. Proceedings of the Asia-Pacific Research in Social Sciences and Humanities, Depok, Indonesia, November 7-9, 2016, 843-850.

Laksmi. (2015). Menumbuhkan budaya informasi melalui lembaga informasi. Prosiding Seminar Nasional: Bahasa, Sastra, dan Perpustakaan. "Pembangunan Karakter Bangsa melalui Penggalian Nilainilai Luhur Budaya." Padang, 23 Mei 2015,7-18.

Litwin, R. (2010). The library paraprofessional movement and the deprofessionalization of librarianship. Progressive Librarian, No. 33 (Summer/Fall 2009), 43-60. This version is slightly revised from the originally published version. Revised January 27, 2010 . 
Lockhart, J. \& Majal, S. (2012). The effect of library staff training and development on the user experience: A case study at the Cape Peninsula University of Technology (CPUT). Proceedings of the IATUL Conferences.Paper 44. Diakses 7 Januari 2017 dari http://docs.lib.purdue.edu/ iatul/2012/papers/44

Pickard, A.J. (2007). Research methods in information. London: facet Publishing.

Qalyubi, S., dkk. (2007). Dasar-dasar ilmu perpustakaan dan informasi.Yogyakarta: UIN Sunan Kalijaga.

Raharso, S. \& Tjahjawati, S.S. (2016). Organisasi berbasis pengetahuan melalui knowledge sharing: kajian komprehensif membangun organisasi yang kompetitif, berbasis pengetahuan, dengan memberdayakan aktivitas knowledge sharing di antara karyawan. Bandung: PenerbitAlfabeta.

Rubin, R.E. (2016). Foundations of library and information science. Fourth edition. Chicago: Neal-Schuman.
Shumaker, D., et al. (2016). Competencies for information professionals. The SLA Board of Directors. Diakses 26 Januari 2018, dari h t t p s : / / w w w. s la . org/about sla/competencies/

Stueart, R.D. \& Moran, B.B. (2007). Library and information center management. Seventh edition. Westport, Connecticut: Libraries Unlimited.

Sulistyo-Basuki. 2013. Keilmuan bidang informasi dan perpustakaan. Diakses 9 Maret 2015, dari https://sulistyobasuki. wordpress.com/2013/03/30/keilmuanbidang-informasi-dan-perpustakaan-2/

Widyastuti, D. (2017). Perpustakaan di tengah hegemoni intelektual. Diakses 21 Oktober 2017, dari http://dip.fisip.unair.ac.id/ perpustakaan-di-tengah-hegemoniintelektual/

Yunita, I. (2016). Kompetensi dan budaya kerja pustakawan menghadapi pasar bebas (Global market). Media Pustakawan, Media Komunikasi antar Pustakawan. 23(1), 2430. 


\section{DAFTAR GAMBAR}

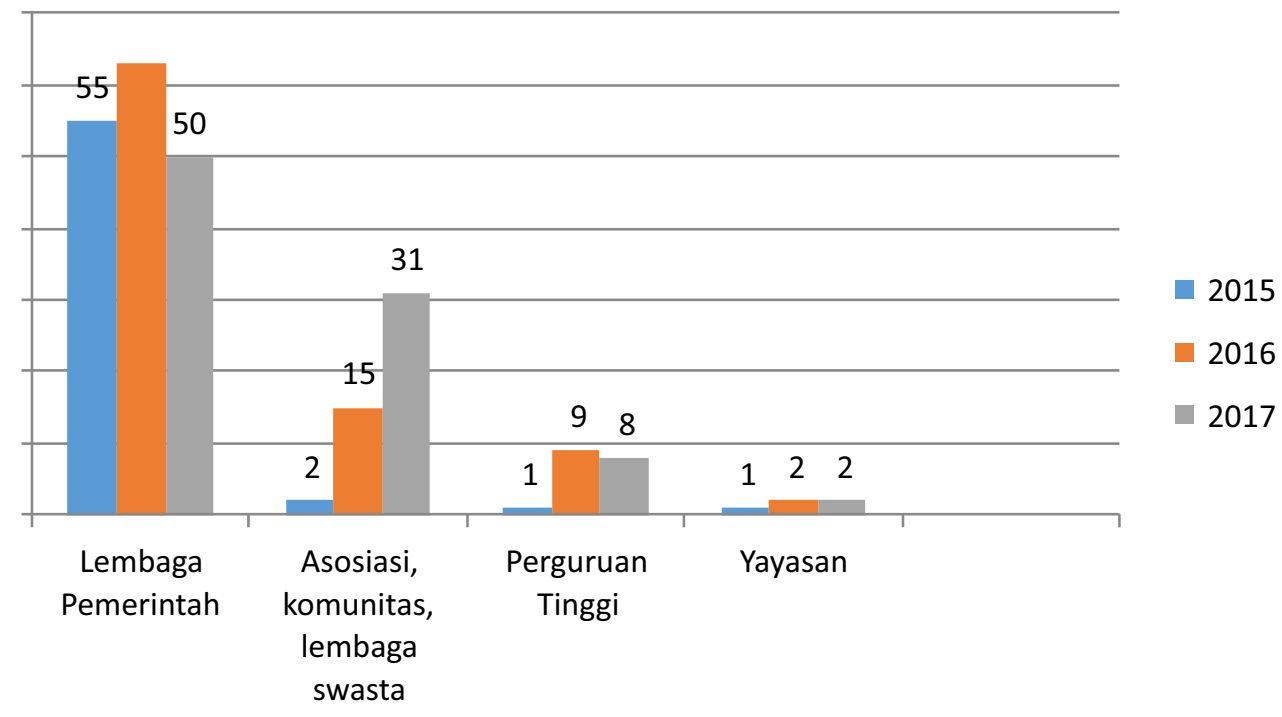

Gambar 1. Penyelenggara diklat tahun 2015-2017

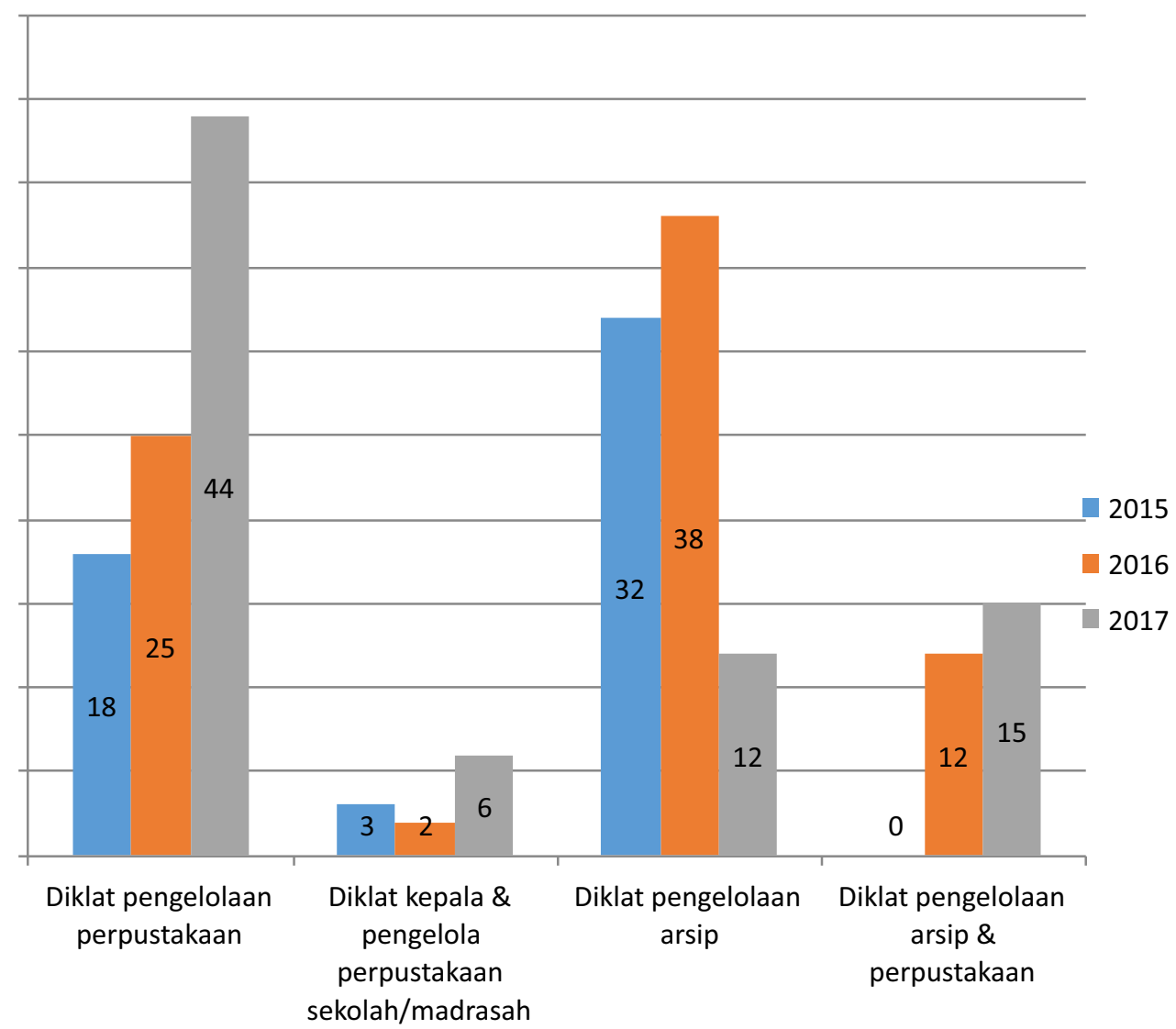

Gambar 2. Topik diklat pengelolaan perpustakaan \& kearsipan, 2015-2017 


\section{DAFTAR TABEL}

Tabel 1. Daftar penyelenggara diklat

\begin{tabular}{|c|c|c|}
\hline No & Kategori & Penyelenggara Diklat \\
\hline 1. & $\begin{array}{l}\text { Lembaga } \\
\text { pemerintah }\end{array}$ & $\begin{array}{l}\text { - Perpustakaan Nasional Republik Indonesia } \\
\text { - Arsip Nasional Republik Indonesia } \\
\text { - Kemenristekdikti Koordinasi Perguruan Tinggi Swasta } \\
\text { - Dinas Pendidikan Provinsi (Sumbar, NTT) } \\
\text { - Dinas Perpustakaan dan Kearsipan tingkat Provinsi (Jakarta, } \\
\text { Yogyakarta, Banyuwangi, Banjarmasin, dan lain -lain) } \\
\text { - Dinas Pendidikan Pemuda dan Olahraga }\end{array}$ \\
\hline 2. & $\begin{array}{l}\text { Asosiasi, } \\
\text { komunitas, } \\
\text { lembaga } \\
\text { swasta lain }\end{array}$ & $\begin{array}{l}\text { - Asosiasi Pustakawan Sekolah Indonesia (ATPUSI) } \\
\text { - Ikatan Pustakawan Indonesia (IPI) } \\
\text { - Asosiasi Pekerja Profesional Informasi Sekolah Indonesia } \\
\text { - Komunitas SLiMS } \\
\text { - Klub Perpustakaan Indonesia } \\
\text { - Manpowerindo.com } \\
\text { - LKP Smile Group } \\
\text { - Lembaga Pembangunan Pendidikan dan Profesi Guru (LP3G) } \\
\text { - Persatuan Guru Madrasah Indonesia (PGMI) Kab. Sidoarjo } \\
\text { - Majelis Pendidikan Katolik (MPK) } \\
\text { - Lembaga Pelatihan Rumah Kreatif Indonesia } \\
\text { - PT Mairodi Mandiri Sejahtera }\end{array}$ \\
\hline 3. & $\begin{array}{l}\text { Perguruan } \\
\text { tinggi }\end{array}$ & $\begin{array}{l}\text { - UIN Sunan Kalijaga } \\
\text { - IAIN Samarinda (UPT Perpustakaan) } \\
\text { - Perpustakaan Universitas 'Aisyiyah Yogyakarta (UNISA) } \\
\text { - Institut Sains \& Teknologi Akad emi Perindustrian Yogyakarta } \\
\text { - Universitas Negeri Malang } \\
\text { - Universitas Negeri Makassar } \\
\text { - Universitas Sanata Dharma Yogyakarta } \\
\text { - Universitas Indonesia (Perpustakaan UI) } \\
\text { - Universitas Padjadjaran } \\
\text { - Unsyiah (UPT Perpustakaan) } \\
\text { - Universitas YARSI } \\
\text { - Badan Musyawarah Perguruan Swasta }\end{array}$ \\
\hline 4. & Yayasan & $\begin{array}{l}\text { - Coca-Cola Foundation Indonesia (CCFI) } \\
\text { - Tanoto Foundation } \\
\text { - LPPPTK KPTK Gowa } \\
\text { - Yayasan Prayoga Riau } \\
\text { - Aceh Library Consultant }\end{array}$ \\
\hline
\end{tabular}

Sumber: Hasil dari analisis data, 2018 